\title{
ANIMALS AND PLANTS IN WINTER
}

\author{
by DIANE SARICH*
}

During the cold days of winter all life must yield to the demanding laws of nature. Most species of birds migrate to warmer climates, some animals hibernate for the winter while others remain more active. The Saskatoon Public Library has several books containing information on what animals do when the cold weather comes:

BARNETT, Samuel A. Instinct and intelligence. 1967. 224 p. This book has material on the migration habits of animals and how they protect themselves against temperature changes.

Y 591.5 B261.

BURTON, Maurice. The sixth sense of animals. 1973. 182 p. Chapter 8 is "Heat and Cold".

591.182 B974

DROSCHER, Vitus B. The magic of the senses. 1969. 298 p. Chapter 2 - "The Temperature Sense"; Chapter 8 - "Migration".

Y 591.18 D787.

KAVALER, Lucy. Life battles cold. 1973. $160 \mathrm{p}$. The incredible ways in which living things have adapted to the cold. Chapter 8 - "Winter in the den"; Chapter 7 — "The secrets of migration".

\section{Y $574.542 \mathrm{~K} 21$}

RUSSELL, Helen R. Winter search party; a guide to insects and other invertebrates. 1971. 171 p. How to look for, recognize, collect, house and observe insects and other small animals in winter.

595.7 R963.

The following books relate the experiences some people have had with animals during winter:

* Saskatoon Public Library,

23rd St. and 4th Ave.,

Saskatoon, Saskatchewan.
ERRINGTON, Paul L. The red gods call 1973. $171 \mathrm{p}$. We follow the author alon game trails from the Big Sioux River it South Dakota to the Big Bog Country ir Minnesota to the Canadian North. Chapte 5-"Winter camps": Chapter $10-$-Win ter in the Big Bay": Chapter 13 - "Winte: at Tetonkaka".

500.9783 E72

HOOVER, Helen. The years of the forest 1973. $318 \mathrm{p}$. The author and her husband spent 16 years in a remote cabin in the Minnesota woods and developed close communications with wildlife, especially the animals they helped through starving winters.

$$
500.9776 \text { H789 }
$$

KNAUTH, Percy. The north woods. 1972 $184 \mathrm{p}$. The forest wildlife from Manitoba and Saskatchewan to Lake Athabasca There are two chapters on winter: "In the grip of winter" and "The bane and blessing of snow".

$500.971 \mathrm{~K} 67$.

OGBURN, Charlton. The winter beach. 1966. $321 \mathrm{p}$. The author followed winter southward from eastern Maine to the North Carolina Banks observing the changes in animals and vegetation.

500.909146034 .

RUSSELL, Franklin. Searchers at the gulf. 1970. 222 p. A season by season account of how the elements affect the creatures of the gulf of a typical river over the period of a year.

591.5 R963.

STEELE, Mary Q. The living year. 1972. 109 p. A rural Tennessee housewife observes the wildlife around her in the garden, fields and woods from spring to spring.

500.9768 S814

TEALE, Edwin M. Wandering through winter. 1965.370 p. A naturalist's record of a 20,000-mile journey through the North American winter.

$574.973 \mathrm{~T} 253 \mathrm{~W}$ 
The following are two books which have good sections on hibernation:

HANCOCKS, David. Master builders of the animal world. 1973. 144 p. Some animals escape the cold by excavating deep within the snow and this book describes the different structures that the animals built for their protection.

$591.56 \mathrm{H} 235$.

KAVALER, Lucy. Freezing point; cold as a matter of life and death. 1970.416 p. How living things adapt to extreme cold, with special attention to the greatest of all animal adaptations - hibernation. Chapter 4 - "Animal adaptations"; Chapter 5 "Migration, hibernation, or mass death"; Chapter 6-"Growth in cold soil".

$574.1916 \mathrm{~K} 21$.

There are different types of hibernation. "True" hibernation takes place only in warm-blooded animals such as some bats and ground squirrels. For information on these mammals you could consult the following books in the library:

HENISCH, Bridget Ann. Chipmunk portrait. 1970. $97 \mathrm{p}$.

Y 599.3232 H511

LAUBER, Patricia. Bats, wings in the night. 1968. $76 \mathrm{p}$. The feeding, breeding and living habits of the many varieties of bats. Y 599.4 L366

MacCLINTOCK, Dorias. Squirrels of North America. 1970. 184 p. Ground squirrels: p. 33-57; Woodchucks and marmots: p. 5-20; Chipmunks: p. 83-103.

599.3232 M 127.

SCHOONMAKER, Walter J. The world of the woodchuck. 1966. $146 \mathrm{p}$.

599.3232 S372

Bears sleep through the winter but are not considered "true" hibernators because their body temperature doesn't drop much below normal. There are two books in the Saskatoon Public Library which have good sections on how bears hibernate.

RUSSELL, Andy. Grizzly country. 1967. 302 p. Chapter 2 contains the natural history of the bear, his habitat, range and habits.

599.74446 R961.
VAN WORMER, Joe. The world of the black bear. 1966. 163 p. The author follows the bear through a full year. Chapter 5 is on winter.

Y 599.74446 V 285.

Many cold-blooded animals hibernate, such as frogs, lizards, snakes, toads and turtles:

CARR, Archie F. So excellent a fish; a natural history of sea turtles. $1967.248 \mathrm{p}$.

598.13 C311.

FROOM. Barbara. The snakes of Canada. 1972. 128 p. (Another copy in Reference).

598.120971 F 936

PORTER, George. The world of the frog and the toad. $1967.153 \mathrm{p}$. Chapter 5 is on winter and hibernation.

597.8 P845

SMITH, Hobart M. Handbook of lizards; lizards of the United States and of Canada. 1967, c 1946. 557 p. The life history of lizards begins on page 31 .

598.112 S649.

WHITE, William. $A$ frog is born. 1972. 80 p.

Y597.8 W589

WRIGHT, Albert H. Handbook of frogs and toads of the United States and Canada. 1967 C1949. $640 \mathrm{p}$.

597.8 W947.

Food supplies become scarce in the winter and many animals migrate to warmer climates where there is a more plentiful food supply. Here are four general books which cover this subject:

FRISCH, Otto Von. Animal migration. 1969. $125 \mathrm{p}$. The research that has gone into man's attempt to answer the how and why of animal movement and migration.

591.52 F917

JARMAN, Catherine. Atlas of animal migration. 1972. 124 p. The migration of birds, mammals, fish, reptiles, amphibians and insects with relief maps and globes of migration routes. (Another copy in Reference.)

$591.52 J 37$.

ORR, Robert T. Animals in migration. 1970. 303 p. The types of population movements, the reasons for migration and the environmental influences on migration.

591.52075 
RICARD, Matthew. The mystery of animal migration. 1968. 209 p. The migratory patterns of many animals, with birds in the greatest detail. (Another copy in Reference).

$591.52 \mathrm{R} 487$.

Every winter most birds fly to a warmer climate. There are several books in the library which cover this subject:

BARRUEL, Paul. Birds of the world; their life and habits. 1973.222 p. Chapter 3 is on migration. (Another copy in Reference.)

Y598.2 B278.

BRUUN, Bertel. The Dell encyclopedia of birds. 1974. 240 p. Bird behavior and migration patterns, nesting and feeding habits.

598.203 B913.

DORST, Jean. The migrations of birds. 1962. $476 \mathrm{p}$. The principal methods of studying the seasonal migration of birds.

598.252 D 718.

GRIFFIN, Donald R. Bird migration. 1964. $180 \mathrm{p}$.

Y 598.252 G851.

KAUFMANN, John. Wings, sun and stars, the story of bird migration. 1969. 159 p.

Y 598.252 K21

McELROY, Thomas P. The habitat guide to birding. 1974. 257 p. Chapter 14 is "Watching songbirds in winter". (Another copy in Reference.)

598.2073 M 141

MAY, Charles P. A book of Canadian birds. 1967. 115 p. Description of 28 common birds found in Canada with information about their habits and habitat.

Y 598.2971 M466.

One method of gathering information about animals during the winter is by observing their tracks. Two helpful books on this subject are:

MURIE, Olaus Johan. A field guide to animal tracks. 1954. 374 p. This book includes all the mammals of North America as well as many birds and insects. (Another copy in Reference.)

$591.5 \mathrm{M} 977$

WEBSTER, David. Track watching. 1972. 89 p. How to become an amateur track watcher.

Y $591.5 \mathrm{~W} 378$.
Winter is not a season of reproduc tion and all plant life lies dormant The following books about plant discuss how they survive the winter:

KAVALER, Lucy. Life battles cold. 1973 160 p. Chapter 10 _ "When microbe rest": Chapter 11 - "Do not walk on th masses": Chapter 12 - "Plants meet th test": Chapter 13 - "The seeds survive". Y $574.542 \mathrm{~K} 2$

NORTHEN, Henry T. Ingenious kingdom the remarkable world of plants. 1970. $274 \mathrm{p}$ Chapter 12 - "Calendars and clocks" Chapter 13 - "Adaptations to environ ment".

$581 \mathrm{~N} 874$

The world of plants, 1965. 160

Part Five - "The climates and seasons". discussion of the effects of cold begins or page 102.

Fish seem to have made the most successful adaptation to cold. Lucy Kavaler discusses fish in Chapter 5 of her book Life battles cold. Two other books which would be helpful are:

COOPER, Allan. Fishes of the world. 1971. 159 p. Chapter 14 - "Adaptations in fresh water": Chapter 17 - "Adaptations in the sea"; Chapter 24 - "Migrations".

597 C776

LAGLER, Karl F. Ichthyology. 1962. 545 p. A discussion of temperature begins on page 433.

$597 \mathrm{~L} 175$

Most insects lie dormant in the soil beneath the snow. Many butterflies and moths hibernate in a cocoon stage. The following books deal with insects:

CALLAHAN, Philip S. Insect behavior. 1970. $155 \mathrm{p}$. The ways in which insects have managed to adapt to their environments. Chapter 7 - "Of home and the weather"

Y 595.7 C156.

HOOPER, Ronald R. The Butterflies of Saskatchewan. 1973. 216 p. The habits, life histories, and identification of Saskatchewan butterflies. (Another copy in Reference.)

$595.789 \mathrm{H} 787$.

HUTCHINS, Ross E. Insects. 1966. 324 p. Chapter 5 - "Insect migration": Chapter 2 _ "Instinct, intelligence and behavior".

$595.7 \mathrm{H} 974$. 
TWEEDIE, Michael. Insects. 1973. 72 p. 101 colour photographs and accounts of each insect's habits and life history.

595.7 T971i.

URQUHART, Frederick A. The Monarch butterfly. 1960.361 p. Chapter 3 covers the subject of migration.

595.789 U79.

Some animals live in a winter atmosphere all year long:

LONG, Tony. Mountain animals. 1971. 152 p. How animals from migrating lemmings and snow finches to giant pandas survive in this remote area above the tree-line.

Y 591.90943 L849.

PERRY, Richard. The polar worlds. 1973. $316 \mathrm{p}$. The life histories and interrelationships of native species of the Arctic and Antarctic regions.

591.998 P464.

STONEHOUSE, Bernard. Animals of the Antarctic. 1972. $171 \mathrm{p}$. The land animals of this region and their curious adaptations for surviving on the world's coldest continent.

Y591.998 S881.
SUTTON, George M. High Arctic. 1971. $116 \mathrm{p}$. The birds and mammals of Bathurst Island.

500.97122 S967.

The Children's Department of the Saskatoon Public Library has a text for young naturalists who are curious about the winter habits of North American wildlife. It is called Where they go in winter, by Margaret Waieny BUCK. 1968. 72 p.

$$
\text { J591.5 B922w. }
$$

There is a good book on this subject which isn't available at the Saskatoon Public Library. It is now out of print but might be available in other libraries or on interlibrary loan. It is called Field book of animals in winter by Ann H. MORGAN. It was published in 1939 and has 527 pages. It is an introduction to the ways in which animals meet the crises and depressions of winter. Chapter 3 is on seasonal migrations and Chapter 4 is about hibernation.

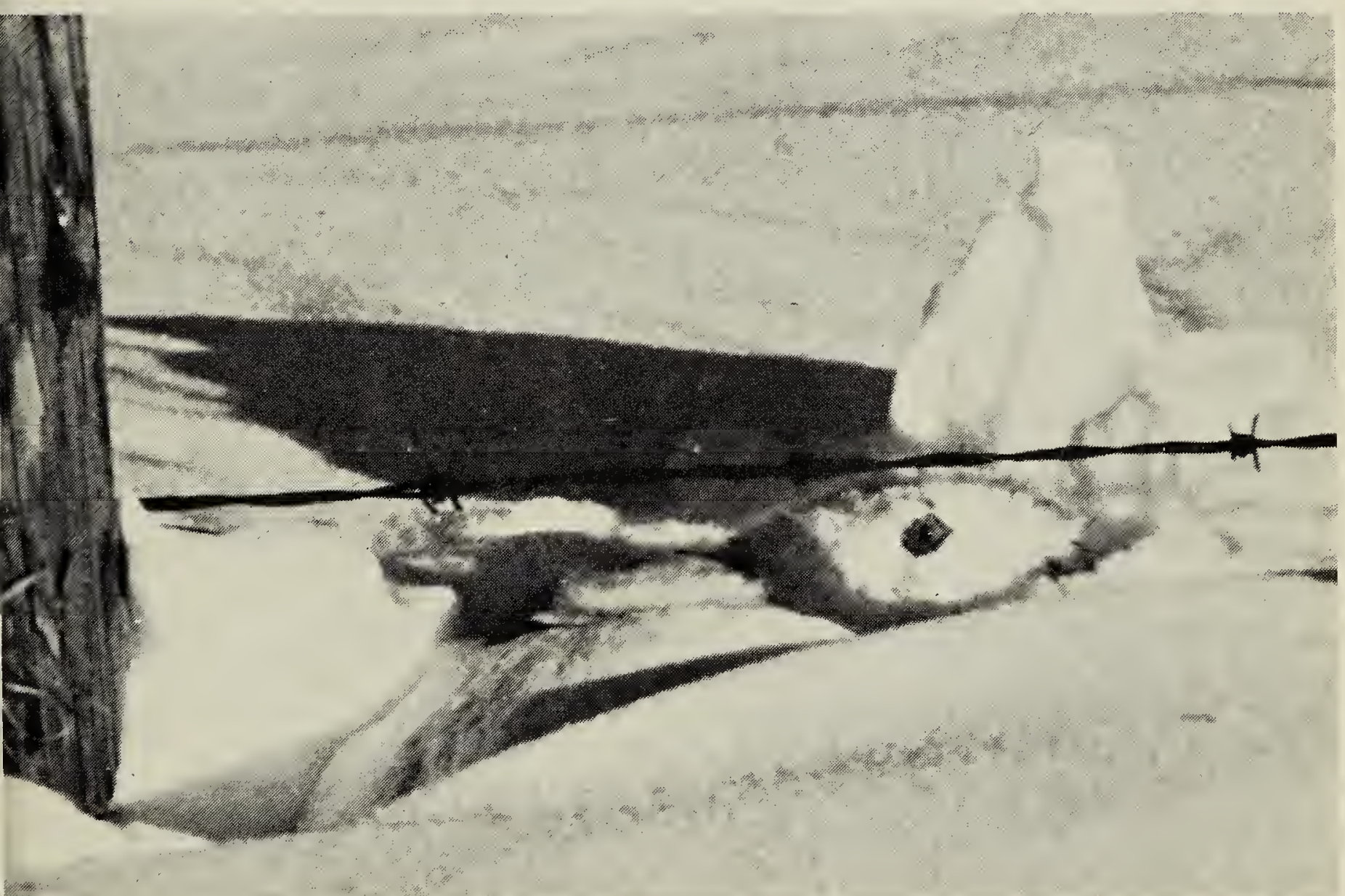

Sinowshoe Hare

R. E. Gehlert 